\title{
Analysis and Performance Optimization of Variable Compression Ratio Diesel Engine using Canola Oil Based Biodiesel
}

\author{
R. R. Honkalas ${ }^{1}$, H. B. Kulkarni2 ${ }^{2}$, P. R. Kubade ${ }^{3}$ \\ ${ }^{1}$ Department of Mechanical Engineering, N.B.N. Sinhgad College of Engineering, Maharashtra, India \\ ${ }^{2}$ School of Mechatronics Engineering, Symbiosis Skills \& Open University, Pune, Maharashtra, India \\ ${ }^{3}$ Department of Mechanical Engineering, KIT's College of Engineering, Maharashtra, India
}

\section{PAPER INFO}

\section{Paper history:}

Received 15 January 2020

Accepted in revised form 23 February 2020

\section{Keywords:}

ANOVA

Brake Power

Brake Thermal Efficiency

Canola Based Biodiesel

Taguchi Method

Variable Compression Ratio Engine

\author{
$A B S T A R A C T$
}

Rapid development of the global economy demands huge amount of Energy. Transportation sector contributes major part of economy development. Fossil fuels like Petrol and Diesel are used for transportation and heavy duty vehicles. Higher rate of consumption of these naturally available fuels leads to its depletion and deterioration of environment. To solve such issue many researchers are interested in identifying and using alternative fuels for internal combustion engines. Biodiesel is renewable fuel and can be used as alternative fuel for Diesel engines. In present work Canola oil based Biodiesel (COB) is blended in Diesel with different concentration like B20, B40 and B60. Engine input variables like compression ratio $(13: 1,15: 1,17: 1)$ and load $(4,8,12 \mathrm{~kg})$ are considered to optimize the results. The Performance of Variable Compression Ratio (VCR) Diesel Engine is evaluated using Taguchi method. Analysis of variance is conducted to recognise the significance of input variables on Brake Thermal Efficiency, Brake power Specific Fuel Consumption. Results of optimization showed that load is the most crucial factor which affects the engine performance i.e. Increase in load decrease the Brake Thermal Efficiency, Brake Power and increases the Specific Fuel Consumption.

doi: 10.5829/ijee.2020.11.01.02

\section{INTRODUCTION}

Alternative or non-conventional fuels, are the combustibles material and can be used as fuels like conventional fuels, like fossil fuels [1]. Compressed Natural Gas (CNG) [2], Liquefied Petroleum Gas (LPG) [3], Ethanol [4], Biogas [5] and Biofuels $[6,7]$ etc. are known as alternative fuels. Bio fuels are derived from biomass i.e. plant material or animal waste. Since biomass is readily available they are called as renewable energy sources. Biodiesels possess similar characteristics as compared to conventional Diesel. Soybean oil [8,9], corn oil [10, 11], sunflower oil [12], rapeseed oil $[13,14]$ and palm oil $[15,16]$, algae $[17,18]$, Jatropha [19, 20] are other major resources of biodiesel worldwide. Recycled grease [21, 22], oils [23] as well as animal fats [24] can also be used for production of biodiesel. Biodiesel is compatible with Diesel and can be blended in different concentration [12] e.g. blend B40 represents $40 \%$ Biodiesel mixed with $60 \%$ diesel. Further no engine modification is required for experimentation. In present work Canola Oil Based Biodiesel (COB) is considered because canola seeds production is in greater amount than other oil seed crops, leading to increased canola oil production. Canola oil is manufactured through the process of transesterification; oil is further treated with alcohol to remove the glycerin. The most common blends are B20, B40 and B60. Properties of COB are summarized in Table 1.

\section{EXPERIMENTAL SETUP}

A Computerized Variable Compression ratio (4stroke, single cylinder, VCR, Product Code 234) diesel engine fitted with Eddy current type dynamometers (manufactured by Apex Innovation, Sangli) is used for conducting experimentation. Initially VCR engine is fueled with pure diesel to start the engine and further it is operated on biodiesel. Canola based biodiesel was purchased from SVM Agro Processor, Nagpur, India. Figure 1 shows experimental setup and Table 2 shows the VCR engine specifications.

\section{OPTIMIZATION OF VCR ENGINE PERFORMANCE}

Taguchi method was developed a method for the design of experiments based on well-structured guidelines. In this 
TABLE 1. Properties of canola oil based biodiesel (ref. Svm agro pvt. Ltd)

\begin{tabular}{|c|c|c|c|c|c|}
\hline $\begin{array}{l}\text { Sr. } \\
\text { No }\end{array}$ & Parameter & Units & Results & Standard & Protocol \\
\hline 1 & Density: $15^{\circ} \mathrm{C}$ & $\mathrm{kg} / \mathrm{m}^{3}$ & 885.0 & $860-900$ & IS:1448(P:16/32) \\
\hline 2 & $\begin{array}{c}\text { Kinematic } \\
\text { Viscosity at } \\
40^{\circ} \mathrm{C}\end{array}$ & Cst & 8.00 & $2.5-8.0$ & IS:1448(P:25) \\
\hline 3 & $\begin{array}{c}\text { Flash } \\
\text { Point(PMCC) }\end{array}$ & ${ }^{\circ} \mathrm{C}$ & 140 & $120 \mathrm{~min}$ & IS:1448(P:21) \\
\hline 4 & $\begin{array}{l}\text { Water } \\
\text { Content }\end{array}$ & $\mathrm{mg} / \mathrm{kg}$ & 60 & $500 \max$ & IS:1993 \\
\hline 5 & Acid Value & $\mathrm{mgKOH} / \mathrm{g}$ & 0.5 & $0.5 \max$ & $\begin{array}{c}\text { IS:1448(P:1)- } \\
1971\end{array}$ \\
\hline 6 & $\begin{array}{c}\text { Gross } \\
\text { calorific value }\end{array}$ & $\mathrm{kcal} / \mathrm{kg}$ & 9550 & - & - \\
\hline
\end{tabular}

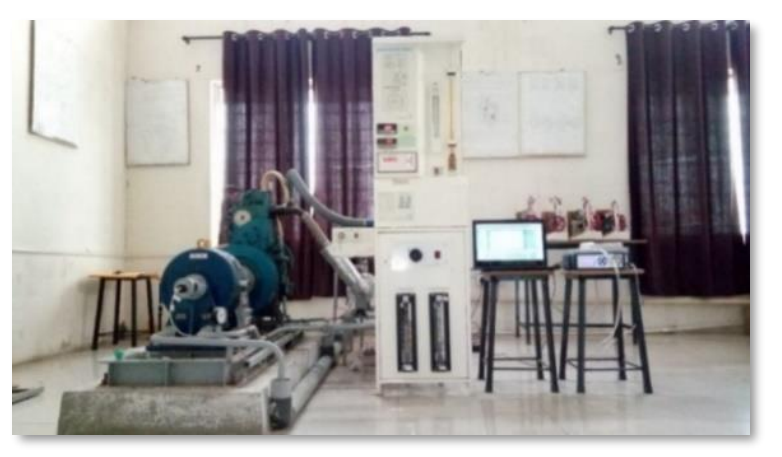

Figure 1. Computerized VCR engine test setup

TABLE 2. VCR engine specification

\begin{tabular}{lcc}
\hline Sr. No. & Information & Specification \\
\hline 1 & Manufacturer & Kirloskar Oil Engines Ltd, India \\
2 & No. of Cylinders & 1 \\
3 & No. of Strokes & 4 \\
4 & Fuel & Diesel \\
5 & Rated Power & $3.5 \mathrm{~kW} @ 1500 \mathrm{rpm}$ \\
6 & Compression Ratio Range & $12 \quad$ o 18.1 \\
\hline
\end{tabular}

method set of orthogonal arrays are used for conducting minimum number of experiments which may predict full information about the factors that are affecting the performance parameter with their percentage of contribution [25-27]. The important point need to be considered while constructing the orthogonal arrays is the selection of levels and combinations of input parameters for each experiment. Table 3 shows the selection of parameters and levels for optimization work.

\section{Selection of orthogonal array and experimental results}

In present work, three input parameters with three levels are selected and L27 orthogonal array is considered. Total twenty-seven experiments were conducted and output Parameters i.e. results are mentioned in Table 4 below.
TABLE 3. Selection of input parameters with levels

\begin{tabular}{lccccc}
\hline Sr. No. & Factor & Levels & Level 1 & Level 2 & Level 3 \\
\hline 1 & Compression Ratio & 3 & 13 & 15 & 17 \\
2 & Load (kg) & 3 & 4 & 8 & 12 \\
3 & Biodiesel Blend (\%) & 3 & B20 & B40 & B60 \\
\hline
\end{tabular}

TABLE 4. Taguchi L9 orthogonal array

\begin{tabular}{|c|c|c|c|c|c|c|}
\hline 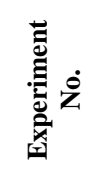 & 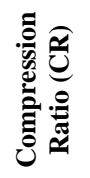 & 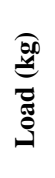 & 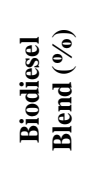 & 至 & 可 & 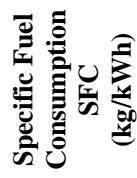 \\
\hline 1 & 13 & 4 & B20 & 1.14 & 16.34 & 0.52 \\
\hline 2 & 13 & 4 & B40 & 1.15 & 16.43 & 0.52 \\
\hline 3 & 13 & 4 & B60 & 1.12 & 17.49 & 0.49 \\
\hline 4 & 13 & 8 & B20 & 2.14 & 24.54 & 0.35 \\
\hline 5 & 13 & 8 & B40 & 2.37 & 24.02 & 0.36 \\
\hline 6 & 13 & 8 & B60 & 2.22 & 20.13 & 0.43 \\
\hline 7 & 13 & 12 & B20 & 3.31 & 25.91 & 0.33 \\
\hline 8 & 13 & 12 & B40 & 3.17 & 26.00 & 0.33 \\
\hline 9 & 13 & 12 & B60 & 3.24 & 27.92 & 0.31 \\
\hline 10 & 15 & 4 & B20 & 1.11 & 14.69 & 0.58 \\
\hline 11 & 15 & 4 & B40 & 0.99 & 15.53 & 0.55 \\
\hline 13 & 15 & 4 & B60 & 1.18 & 18.42 & 0.47 \\
\hline 14 & 15 & 8 & B20 & 2.21 & 23.82 & 0.36 \\
\hline 15 & 15 & 8 & B40 & 2.39 & 24.16 & 0.35 \\
\hline 17 & 15 & 8 & B60 & 2.20 & 23.70 & 0.36 \\
\hline 18 & 15 & 12 & B20 & 3.23 & 27.84 & 0.31 \\
\hline 19 & 15 & 12 & B40 & 3.34 & 26.09 & 0.33 \\
\hline 20 & 15 & 12 & B60 & 3.38 & 26.43 & 0.32 \\
\hline 21 & 17 & 4 & B20 & 1.13 & 17.71 & 0.48 \\
\hline 22 & 17 & 4 & B40 & 1.05 & 16.50 & 0.52 \\
\hline 23 & 17 & 4 & B60 & 1.17 & 30.56 & 0.28 \\
\hline 24 & 17 & 8 & B20 & 2.21 & 25.31 & 0.34 \\
\hline 25 & 17 & 8 & B40 & 2.26 & 24.34 & 0.35 \\
\hline 26 & 17 & 8 & B60 & 2.24 & 96.45 & 0.09 \\
\hline 27 & 17 & 12 & B20 & 3.18 & 30.45 & 0.28 \\
\hline
\end{tabular}

\section{Analysis of variance (ANOVA)}

Analysis of variance (ANOVA) is a statistical method used to identify the differences among group means in sample experiments, it is based on the law of total variance where observed variance in particular variable is divided into components attributes to various sources of variation [28].

\section{Signal to noise ratio (S/N Ratio)}

Taguchi method is used in present work to minimize the variations in the performance due to presence of undesirable factors called noise. Signal to noise ratio is high which means there is minimum effects of the noise of experiments. There are three different types of $\mathrm{S} / \mathrm{N}$ ratio such as larger the better, 
smaller the better and nominal the best. Selection of $\mathrm{S} / \mathrm{N}$ ratio depends on the objective of research work [29].

\section{RESULTS AND DISCUSSION}

The main objective of present work is to optimize the output parameters i.e. Brake power (BP), Brake Thermal Efficiency (BTE) and Specific Fuel Consumption (SFC). Brake power and Brake Thermal Efficiency of the VCR engine should be high as possible so 'Larger is better' $\mathrm{S} / \mathrm{N}$ ratio is considered and Specific Fuel Consumption (SFC) should be less so "smaller is better" $\mathrm{S} / \mathrm{N}$ ratio is considered.

Figure 2 shows the main effect plot for SN ratios of Brake Power; Maximum Mean value for Brake power is 6.1106 at $13 \mathrm{CR}, 10.2774$ at $12 \mathrm{~kg}$ load and 6.1800 at B60 blend. Minimum Mean value for Brake power is 6.0505 at $17 \mathrm{CR}$, 0.9380 at $4 \mathrm{~kg}$ load and 6.0132 at B20 blend. Delta value is the difference between maximum and minimum value of Mean [30].

Table 5 shows the response table for Brake Power, here $\mathrm{S} / \mathrm{N}$ ratio is larger the better. Maximum value of Delta is for load i.e. 9.3393 having rank 1 and minimum i.e. 0.0601 for Compression ratio having rank 3 , it means Load is having maximum and compression ratio is having minimum effect of on Brake Power [31] this result can be confirmed with $\mathrm{S} / \mathrm{N}$ ratio and ANOVA $[32,33]$.

From Tables 5 and 6, it is clear that load affects at about $99.42 \%$ on Brake Power of VCR Engine. Figure 3 shows the main effect plot for SN ratios of Brake Thermal Efficiency; Maximum Mean value for Brake Thermal Efficiency is 29.47 at $17 \mathrm{CR}, 29.10$ at $12 \mathrm{~kg}$ load and 29.17 at B60 blend. Minimum Mean value for Brake Thermal Efficiency is 26.71 at $13 \mathrm{CR}, 24.99$ at $4 \mathrm{~kg}$ load and 26.79 at B40 blend. Delta value is obtained by subtracting minimum value of Mean from maximum value of mean.

Table 7 shows the response table for Brake Thermal Efficiency, here $\mathrm{S} / \mathrm{N}$ ratio is larger the better. Maximum value of Delta is for load i.e. 4.11 having rank 1 and minimum i.e. 2.38 for Blend having rank 3, it means Load is having maximum and blend is having minimum effect of on Brake Thermal Efficiency this result can be confirmed with $\mathrm{S} / \mathrm{N}$ ratio and ANOVA. From Tables 7 and 8, though error in this experiment is $57.87 \%$ but also load affects at about $30.97 \%$ on Brake Thermal Efficiency of VCR Engine.

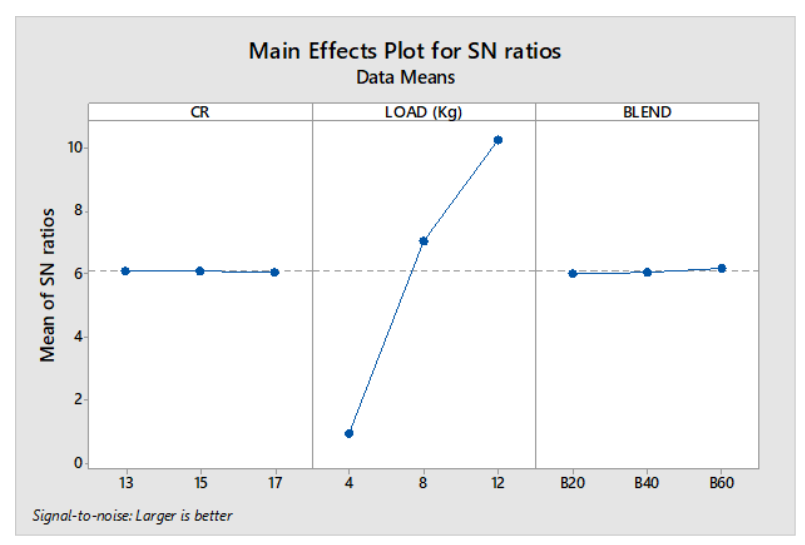

Figure 2. Main effect plot for SN ratios of brake power
TABLE 5. Response table for brake power (larger the better)

\begin{tabular}{lccc}
\hline Level & CR & Load $(\mathbf{k g})$ & Blend \\
\hline 1 & 6.1106 & 0.9380 & 6.0132 \\
2 & 6.0887 & 7.0344 & 6.0566 \\
3 & 6.0505 & 10.2774 & 6.1800 \\
Delta Value & 0.0601 & 9.3393 & 0.16667 \\
Rank & 3 & 1 & 2 \\
\hline
\end{tabular}

TABLE 6. Analysis of variance for brake power

\begin{tabular}{lcccccc}
\hline Source & DF & Adj SS & Adj MS & $\begin{array}{c}\text { F- } \\
\text { Value }\end{array}$ & $\begin{array}{c}\text { P- } \\
\text { Value }\end{array}$ & $\begin{array}{c}\text { Percentage } \\
(\%)\end{array}$ \\
\hline CR & 2 & 0.0036 & 0.0018 & 0.33 & 0.721 & 0.017 \\
Load (Kg) & 2 & 20.8217 & 10.4108 & 1912.19 & 0.000 & 99.42 \\
Blend & 2 & 0.0088 & 0.0044 & 0.81 & 0.459 & 0.0420 \\
Error & 20 & 0.1089 & 0.0054 & & & 0.52 \\
Total & 26 & 20.9430 & & & & 100 \\
\hline
\end{tabular}

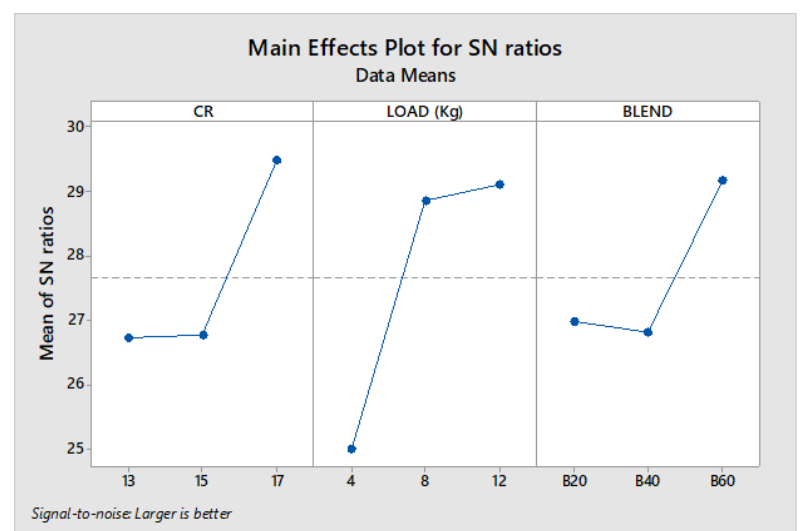

Figure 3. Main effect plot for SN ratios of brake thermal efficiency

TABLE 7. Response table for brake thermal efficiency (larger the better)

\begin{tabular}{lccc}
\hline Level & CR & Load $(\mathbf{K g})$ & Blend \\
\hline 1 & 26.71 & 24.99 & 26.98 \\
2 & 26.76 & 28.85 & 26.79 \\
3 & 29.47 & 29.10 & 29.17 \\
Delta Value & 2.76 & 4.11 & 2.38 \\
Rank & 2 & 1 & 3 \\
\hline
\end{tabular}

TABLE 8. Analysis of variance for brake thermal efficiency

\begin{tabular}{lcccccc}
\hline Source & DF & Adj SS & $\begin{array}{c}\text { Adj } \\
\text { MS }\end{array}$ & $\begin{array}{c}\text { F- } \\
\text { Value }\end{array}$ & $\begin{array}{c}\text { P- } \\
\text { Value }\end{array}$ & $\begin{array}{c}\text { Percentage } \\
(\%)\end{array}$ \\
\hline CR & 2 & 895.5 & 447.8 & 2.59 & 0.100 & 14.94 \\
Load (Kg) & 2 & 923.0 & 461.5 & 2.67 & 0.094 & 30.97 \\
Blend & 2 & 700.6 & 350.3 & 2.02 & 0.158 & 11.71 \\
Error & 20 & 3461.0 & 173.1 & - & - & 57.87 \\
Total & 26 & 5980.1 & - & - & - & 100 \\
\hline
\end{tabular}


Figure 4 shows the main effect plot for $\mathrm{SN}$ ratios of Specific Fuel Consumption; Maximum Mean value for Brake Thermal Efficiency is 10.843 at $17 \mathrm{CR}, 10.467$ at $12 \mathrm{~kg}$ load and 10.506 at B60 blend. Minimum Mean value for Specific Fuel Consumption is 8.035 at $13 \mathrm{CR}, 6.305$ at $4 \mathrm{~kg}$ load and 8.153 at B40 blend.

Table 9 shows the response table for Specific Fuel Consumption; here $\mathrm{S} / \mathrm{N}$ ratio is smaller the better. Maximum value of Delta is for load i.e. 4.117 having rank 1 and minimum i.e. 2.353 for Blend having rank 3, it means Load is having maximum and blend is having minimum effect of on Specific Fuel Consumption. This result can be confirmed with $\mathrm{S} / \mathrm{N}$ ratio and ANOVA. From Tables 9 and 10, error in this experiment is $20.88 \%$ and load affects at about $56.27 \%$ on Specific Fuel Consumption of VCR Engine.

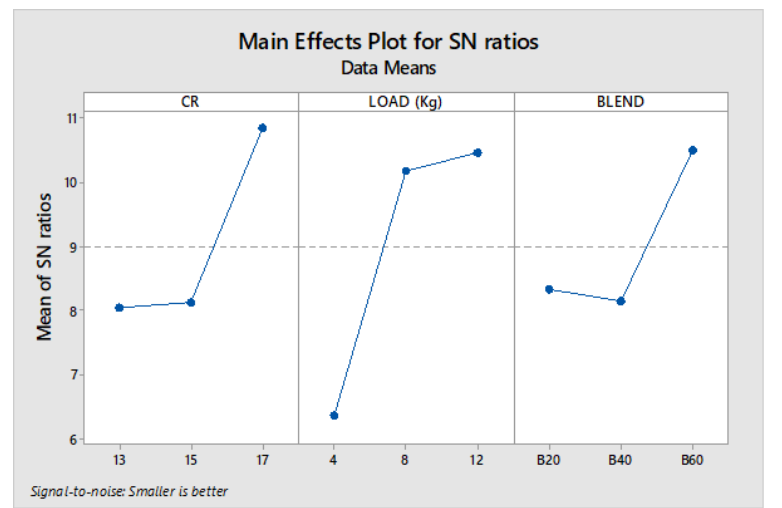

Figure 4. Main effect plot for $\mathrm{SN}$ ratios of specific fuel consumption

TABLE 9. Response table for specific fuel consumption (smaller the better)

\begin{tabular}{lccc}
\hline Level & CR & Load $(\mathbf{K g})$ & Blend \\
\hline 1 & 8.035 & 6.350 & 8.334 \\
2 & 8.116 & 10.177 & 8.153 \\
3 & 10.843 & 10.467 & 10.506 \\
Delta Value & 2.808 & 4.117 & 2.353 \\
Rank & 2 & 1 & 3 \\
\hline
\end{tabular}

TABLE 10. Analysis of variance for specific fuel consumption

\begin{tabular}{lcccccc}
\hline Source & DF & Adj SS & Adj MS & $\begin{array}{c}\text { F- } \\
\text { Value }\end{array}$ & $\begin{array}{c}\text { P- } \\
\text { Value }\end{array}$ & $\begin{array}{c}\text { Percentage } \\
(\%)\end{array}$ \\
\hline CR & 2 & 0.04565 & 0.022826 & 6.71 & 0.006 & 14.02 \\
Load $(\mathrm{Kg})$ & 2 & 0.18316 & 0.091581 & 26.94 & 0.000 & 56.27 \\
Blend & 2 & 0.02867 & 0.014337 & 4.22 & 0.030 & 8.80 \\
Error & 20 & 0.06799 & 0.003399 & & & 20.88 \\
Total & 26 & 0.32547 & & & & 100 \\
\hline
\end{tabular}

\section{CONCLUSION}

An experimental evaluation and Taguchi based optimization is carried out on Single Cylinder VCR Diesel Engine with variable compression ratios and load using Canola based biodiesel. Taguchi method is used to find out effect of input parameters which are directly affecting the output. Contribution of individual parameter on output parameters such as Brake Power, Specific Fuel Consumption and Brake Thermal Efficiency is evaluated.

Results of Taguchi based optimization show that load is the most critical factor which directly affects the engine performance i.e. Increase in load decrease the value of Brake Power, Brake Thermal Efficiency and increases the Specific Fuel Consumption and vice versa. Contribution of Load on variation of Brake Power, Brake Thermal Efficiency and Specific Fuel Consumption is $99.42 \%, 30.97 \%$ and $56.27 \%$, respectively.

Further it is observed that Biodiesel is not affecting much on output parameters and its contribution is very less like $0.420 \%, 11.71 \%$ and $8.80 \%$ on Brake Power, Brake Thermal Efficiency and Specific Fuel Consumption, respectively. As percentage contribution is less than $10 \%$ it means Biodiesel can be used as fuel to conventional Diesel fuel.

It is observed that VCR Engine can perform very well when compression ratio is 17 , load on the engine is $8 \mathrm{~kg}$ and Biodiesel at B60. From the results obtained from experimentation and optimization Highest Brake power i.e. $3.38 \mathrm{~kW}$ can be produced at B60, and Highest Brake Thermal Efficiency and Lowest Specific Consumption can be obtained Biodiesel at B60. If manufacturing costs get reduced and availability of Biodiesel is made easily then it can be used as alternative fuel for Diesel Engine.

\section{REFERENCES}

1. Huang, D., Zhou, H. and Lin, L., 2012. Biodiesel: an alternative to conventional fuel. Energy Procedia, 16, pp.1874-1885.

2. Semin, R.A.B., 2008. A technical review of compressed natural gas as an alternative fuel for internal combustion engines. American Journal of Engineering and Applied Sciences, 1(4), pp.302-311.

3. Brynolf, S., Fridell, E. and Andersson, K., 2014. Environmental assessment of marine fuels: liquefied natural gas, liquefied biogas, methanol and bio-methanol. Journal of Cleaner Production, 74, pp.8695.

4. Prasad, S., Singh, A. and Joshi, H.C., 2007. Ethanol as an alternative fuel from agricultural, industrial and urban residues. Resources, Conservation and Recycling, 50(1), pp.1-39.

5. Henham, A. and Makkar, M.K., 1998. Combustion of simulated biogas in a dual-fuel diesel engine. Energy Conversion and Management, 39(16-18), pp.2001-2009.

6. Varuvel, E.G., Mrad, N., Tazerout, M. and Aloui, F., 2012 Experimental analysis of biofuel as an alternative fuel for diesel engines. Applied Energy, 94, pp.224-231.

7. Demirbas, A., 2008. Biofuels sources, biofuel policy, biofuel economy and global biofuel projections. Energy Conversion and Management, 49(8), pp.2106-2116.

8. Canakci, M. and Van Gerpen, J.H., 2003. Comparison of engine performance and emissions for petroleum diesel fuel, yellow grease biodiesel, and soybean oil biodiesel. Transactions of the ASAE, 46(4), pp.937-944.

9. Knothe, G., Van Gerpen, J.H. and Krahl, J., 2005. The biodiesel handbook (Vol. 1). Champaign, IL: AOCS press.

10. Demirbas, A., 2009. Political, economic and environmental impacts of biofuels: A review. Applied Energy, 86, pp.S108-S117.

11. Hu, J., Du, Z., Li, C. and Min, E., 2005. Study on the lubrication properties of biodiesel as fuel lubricity enhancers. Fuel, 84(12-13), pp.1601-1606.

12. Demirbas, A., 2008. Biodiesel. Springer London. 
13. Ma, F. and Hanna, M.A., 1999. Biodiesel production: a review. Bioresource Technology, 70(1), pp.1-15.

14. Šimáček, P., Kubička, D., Šebor, G. and Pospíšil, M., 2009. Hydroprocessed rapeseed oil as a source of hydrocarbon-based biodiesel. Fuel, 88(3), pp.456-460.

15. Mofijur, M., Masjuki, H.H., Kalam, M.A., Atabani, A.E., Fattah, I.R. and Mobarak, H.M., 2014. Comparative evaluation of performance and emission characteristics of Moringa oleifera and Palm oil-based biodiesel in a diesel engine. Industrial Crops and Products, 53, pp.7884.

16. Al-Widyan, M.I. and Al-Shyoukh, A.O., 2002. Experimental evaluation of the transesterification of waste palm oil into biodiesel. Bioresource Technology, 85(3), pp.253-256.

17. Ahmad, A.L., Yasin, N.M., Derek, C.J.C. and Lim, J.K., 2011. Microalgae as a sustainable energy source for biodiesel production: a review. Renewable and Sustainable Energy Reviews, 15(1), pp.584593.

18. Chen, Y.H., Huang, B.Y., Chiang, T.H. and Tang, T.C., 2012. Fuel properties of microalgae (Chlorella protothecoides) oil biodiesel and its blends with petroleum diesel. Fuel, 94, pp.270-273.

19. Sahoo, P.K. and Das, L.M., 2009. Combustion analysis of Jatropha, Karanja and Polanga based biodiesel as fuel in a diesel engine. Fuel, 88(6), pp.994-999.

20. Sahoo, P.K., Das, L.M., Babu, M.K.G., Arora, P., Singh, V.P., Kumar, N.R. and Varyani, T.S., 2009. Comparative evaluation of performance and emission characteristics of jatropha, karanja and polanga based biodiesel as fuel in a tractor engine. Fuel, 88(9), pp.1698-1707.

21. Van Gerpen, J., 2005. Biodiesel processing and production. Fuel Processing Technology, 86(10), pp.1097-1107.

22. Groschen, R., 2002. Overview of the feasibility of biodiesel from waste/recycled greases and animal fats. Minnesota Department of Agriculture. http://www.angelfire.com/ks3/go_diesel/files042803/ wastefatsfeasability.pdf.

23. Ozsezen, A.N., Canakci, M., Turkcan, A. and Sayin, C., 2009. Performance and combustion characteristics of a DI diesel engine fueled with waste palm oil and canola oil methyl esters. Fuel, 88(4), pp.629-636.

24. Graboski, M.S. and McCormick, R.L., 1998. Combustion of fat and vegetable oil derived fuels in diesel engines. Progress in Energy and Combustion Science, 24(2), pp.125-164.
25. Prathmesh Mahesh, S. and B Kulkarni India, H., Evaluation of Performance Characteristics and Exhaust Gas Analysis of VCR Engine at Different Compression Ratio and Loads (Research note). Iranian Journal of Energy and Environment, 8(3), pp.230-233.

26. Roy, R.K., 2010. A primer on the Taguchi method. Society of Manufacturing Engineers.

27. Kackar, R.N., 1985. Off-line quality control, parameter design, and the Taguchi method. Journal of Quality Technology, 17(4), pp.176-188.

28. Gopalsamy, B.M., Mondal, B. and Ghosh, S., 2009. Taguchi method and ANOVA: An approach for process parameters optimization ofhard machining while machining hardened steel. Journal of Scientific \& Industrial Research, 68, pp.686-695.

29. Tsui, K.L., 1992. An overview of Taguchi method and newly developed statistical methods for robust design. Iie Transactions, 24(5), pp.44-57.

30. Vellaiyan, S., Subbiah, A. and Chockalingam, P., 2019. Multi-response optimization to obtain better performance and emission level in a diesel engine fueled with water-biodiesel emulsion fuel and nanoadditive. Environmental Science and Pollution Research, 26(5), pp.4833-4841.

31. Modi, M.A., Patel, T.M. and Rathod, G.P., 2014. Parametric optimization of single cylinder diesel engine for palm seed oil \& diesel blend for brake thermal efficiency using Taguchi method. IOSR Journal of Engineering, 4(5), pp.49-54.

32. Kshirsagar, G., 2016. Parametric optimization of abrasive water jet machining of inconel-718 material. International Journal of Research in Engineering and Technology, 3(8), pp.1236-1242.

33. Rao, S.R. and Padmanabhan, G., 2012. Application of Taguchi methods and ANOVA in optimization of process parameters for metal removal rate in electrochemical machining of $\mathrm{Al} / 5 \% \mathrm{SiC}$ composites. International Journal of Engineering Research and Applications (IJERA), 2(3), pp.192-197.

34. Patil, R.J., Kubade, P.R. and Kulkarni, H.B., 2019, December Optimization of machine shop layout by using flexsim software. In $1^{\text {s }}$ International Conference on Manufacturing, Material Science and Engineering, AIP Conference Proceedings (Vol. 2200, No. 1), pp. 020033.1- 020033.14.

35. Kulkarni, H.B. and Kubade, P.R., 2020. Performance Optimization of VCR Diesel Engine Using Soybean Oil-Based Biodiesel. In Emerging Trends in Mechanical Engineering, Springer, Singapore, pp. 365-375.

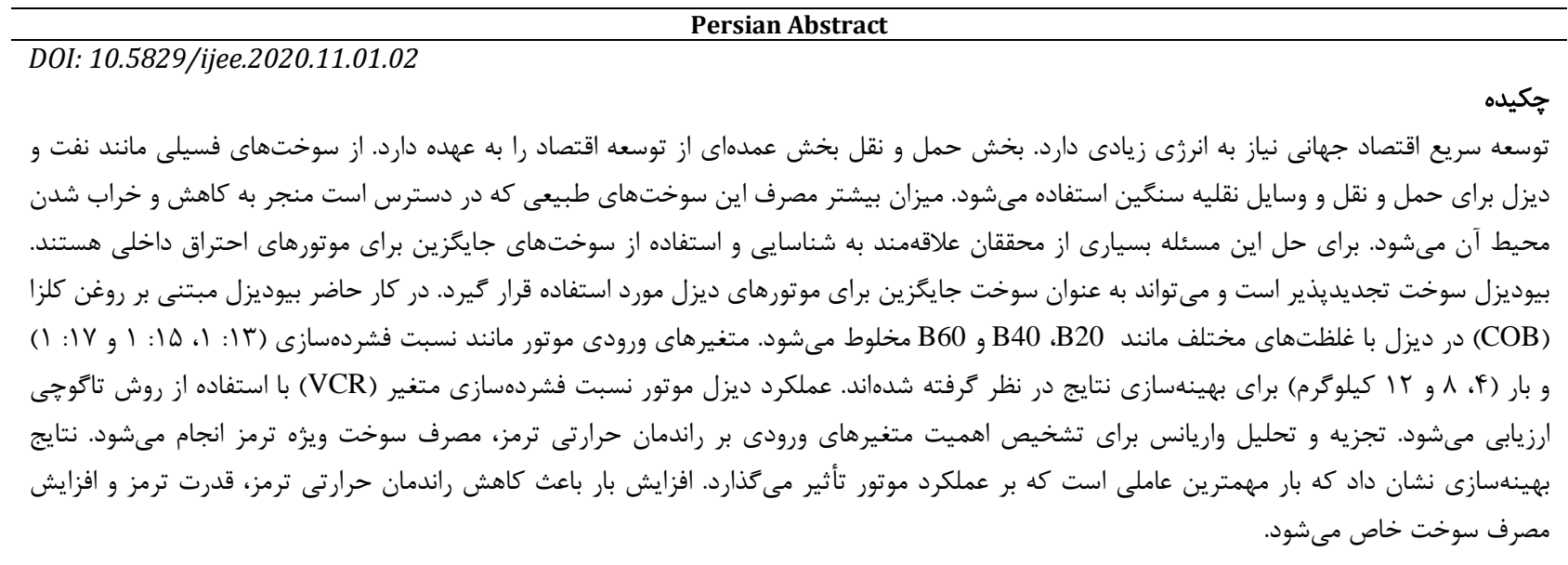

